\title{
Spanish Language Grammatical Context-Acknowledging Specific Language Characteristics
}

\author{
Joel Laffita Rivera \\ Faculty of Applied Communication (FAC), Multimedia University, Selangor, Malaysia \\ Email: Joel.laffita@mmu.edu.my
}

How to cite this paper: Rivera, J. L. (2019). Spanish Language Grammatical ContextAcknowledging Specific Language Characteristics. Open Journal of Modern Linguistics, 9, 215-228.

https://doi.org/10.4236/ojml.2019.93020

Received: April 19, 2019

Accepted: June 27, 2019

Published: June 30, 2019

Copyright (อ 2019 by author(s) and Scientific Research Publishing Inc. This work is licensed under the Creative Commons Attribution International License (CC BY 4.0).

http://creativecommons.org/licenses/by/4.0/

\begin{abstract}
The current research article exposes a linguistic-outline-analysis about the use of Nouns-Object/Thing/Place, Definite and Indefinite Articles and Descriptive Adjectives in the writing and speaking context of Spanish language communication. The teaching and learning of these Spanish grammar themes continue to be subject of interest among scholars due to the level of complexities that these syntaxes present in terms of Second Language Acquisition (SLA) (Bialystok, 1981). The article collected appropriate literature-materials from different sources and added new-contextual-insights into its frame to adhesive an analytical-database with emphasis on Spanish Language Grammatical Contexts that tap into the subject-matter-discussed. Being consecutive to this, the study aimed to provide valuable material as a reference to teach and study these Spanish grammar subjects in Spanish foreign language classes.
\end{abstract}

\section{Keywords}

Learning-Language-Retention, Translation, Grammar-Patterns,

Communication-Insights, Methodology-Schemes

\section{Introduction}

The grammar of the Spanish language is by logical definition "the Spanish grammar", redundant definition but denotes the "authenticity" of this discipline referring to the Spanish language in particular. The following statement quotes that grammar is part of Linguistics which studies the elements of a language as well as the way in which these are organized and combined (Diccionario de la lengua española, 2015). The Spanish language possesses unique grammar shapes and grammatical structures that make this language exclusive and different from other 
languages. For instance, in Spanish the nouns form a two-gender system and are marked for number. This is a fact that reflexes on nouns-object/thing/place. The definite articles, excluding the neuter "lo", and indefinite articles are also marked for gender and number. All grouped "nine in total" and with unique grammar-shapes. Although the adjectives and descriptive adjectives do not have gender in Spanish; they are subjected to follow the same patterns (gender and number) when they adhered to these grammar themes (article/noun) (Batchelor, José, \& Ángel, 2010). The way with which these syntaxes components are treated referring to the use of gender (masculine/feminine) and the number (singular/plural) and the arrangement (words order) of nouns, articles and descriptive adjectives into the writing and speaking context of Spanish language communication makes more challenging the teaching and learning of these grammar themes in Spanish FL classes, essentially when working with 2L learners whose native-language does not apply the "gender/number/words-order" as Spanish does. As a result, the acquisition and development of the linguistic and communicative competences that involve the use of these Spanish grammar themes cannot produce successful language-outputs without acknowledging these distinct-syntaxes-patterns-usages. Based on this overall respect, the research article is addressing its headings and sub-headings.

\section{Learning Language Retention}

Memory plays a vital role in the acquisition of the L2. Learning is to save some memory, and to recall it when it is necessary. Memory and learning, therefore, are closely related. The memory is defined as the test of the learning. This definition of memory as a test of the learning gets relevance when it comes to adequately apply the gender and number in all the linguistic aspects of Spanish language that requires it. It has been cited by many scholars that Spanish 2L learners at all levels mistake in this regard (Rutherford \& Sharwood Smith, 1988). My professional opinion agrees with that of those scholars. According to the finding of this research-article I would say that many of the errors made by $2 \mathrm{~L}$ learners whose native-language does not apply the "gender/number" as Spanish does are directly or indirectly related to the way that that subject-knowledge was acquired, predominantly when it comes to Learning-Language-Retention. The mind of $2 \mathrm{~L}$ learners for instance will choose the easy way of acquiring knowledge versus the hard mode. This means that knowing the "meaning" of a particular phrase that they want to say/write in the L2 rather than studying the linguistic elements that make it up will be sufficient to comprehend it at all. So, in order to achieve the L2-target in a faster way, they will translate from the L1 to L2, but, without taking into account that each language has its own linguistic-characteristics and own linguistic-speaking and writing standards applications context. Even though the use of translation can facilitates the acquisition and development of the speaking-skill; it does not work in the case of applying correctly the gender and number and words-order in nouns-object/thing/place, definite/indefinite articles 
and descriptive adjectives in Spanish if the learners do not acknowledge these distinct-syntaxes-patterns and their usage. Thus, understanding that the mind of the $2 \mathrm{~L}$ learners does not conceived the acquisition of grammar and grammatical structures of the L2 without using the knowledge that it has already been conceived by the L1, it will lead us to emphasis on the significant of acknowledging the L2 own-grammar-patterns in translation by considering the fact that in Spanish nouns-object/thing/place and definite/indefinite articles are marked for gender and number; that the descriptive adjective are subjected to the gender-number-nature of nouns/articles; that it is necessary to know the words-order of nouns/articles/adjectives into the speaking and writing context of Spanish; that there are communication-linguistic-structures that require to be knowledgeable about the use of these Spanish-syntaxes for applying them correctly in this specific field. Furthermore, that there are rules and exceptions related to the use of L2-grammar. In practice, failing in doing this could have adverse effects to the mind of $2 \mathrm{~L}$ learners leading to distortion and inadequate Language-Learning-Retention.

\section{Grammar Patterns-Nouns Object/Thing/Place}

One of the most questionable Spanish language topics in Spanish FL classes is the use of the gender, mostly referring to its application in nouns-object/thing/place. For 2L learners whose native-language does not apply the gender in nouns-object/ thing/pace in the way Spanish does. This often becomes a difficult Spanish language-issue to comprehend and digest. The main reason points to the inference of the L1-mind-subconscious which does not apprehend such irrational-view, I would say. However, from the point of view of language-learning-retention is clear that the keyword required is "acknowledging". It might seem not logical classifying the nature of an object, thing or place in the same way that we do in the case of people or animals when we refer to their gender (male/female). Nonetheless, this is well-seen linguistic-phenomenon in the case of Spanish language own-linguistic-characteristics as well as in others European Languages such as French, Germany, Portuguese and Italian (see Table 1).

Table 1. Nouns object/thing/place gender.

\begin{tabular}{lll}
\hline Nombres/Nouns & Masculine & Feminine \\
\hline auto/car & - & \\
casa/house & - & \\
aula/classroom & - & \\
agua/water & - & \\
sofá/sofa & - & \\
cine/cinema & - & \\
machete/machete & - & \\
banquete/banquet &
\end{tabular}




\section{Continued}

\begin{tabular}{lll}
\hline calle/street & & - \\
llave/key & - & - \\
art/arte & - & - \\
air/aire & & - \\
librería/bookshop & & - \\
universidad/university & - & - \\
educación/education & & \\
profesión/profession & & - \\
hospital/hospital & - & - \\
libertad/liberty & & \\
universo/universe &
\end{tabular}

As can be observed from the above Table 1; it could be difficult to recognize a masculine or feminine noun in the case of objects/things/places. If we think for instance how variable and distinct they are, it could be also a real challenge to master this topic. I essentially say this because in Spanish all nouns referring to objects/things/places have their own-orthography/spelling which cannot be changed in terms of gender-application. In this respect it is necessary to acknowledge these specific-linguistic-traits. For this reason the study has outlined the statements below to provide a clear understanding regarding to the use of gender/number and singular/plural in Objects/Things/Places according to the writing system of Spanish language:

- Usually, the nouns that end in a vowel "o" are masculine (anillo/ palacio/ autol libro) etc. Generally, nouns ending in a vowel "a" are feminine; excluding exceptions of nouns that end in a vowel "a" but are masculine (agualmapalalbalsofá) ext.

- Nouns that end in a vowel "e" can be masculine or feminine. However, by considering that the predominant way in terms of the use of gender in Spanish is "masculine one" and that the number of masculine nouns ending in " $\mathrm{e}$ " is much greater than that of the feminine one, identifying the female between these kinds of nouns is a thing of going for the masculine one. Of course, learners need to count on the help of the Spanish teacher to do so: (cinel restaurantel machetel banquetel pacquetel panquel aceitel aretel callel llave /clase) ext.

- Usually nouns ending in the vowel " $i$ " are masculine (rubil maní) ext.

- The nouns beginning in a vowel "a" are usually masculine (amanecer/atardecer/ambiente/ arte) ext.

Note: Nouns ending in "consonants" can be male or female. However, among these kinds of nouns are those that the following references (syllable) telling us the gender to which they belong.

- Nouns ending in "al"/"ón"/"or" are male (hospitallportall/cristal)/camión/ proyector/ tractor) ext. 
- Nouns ending in "ad"/“zión"/“ción"/“xión" are female (universidadlpopularidadl amistadl profesión/ educación/crucifixión) ext.

\section{Grammar Patterns-Singular/Plural-Nouns}

The singular and plural is generally applied to all nouns. It is easy to recognize the singular nouns since the vast majority of them do not have "s" at the end of the word that referred to them as such. So, the "s" at the end of these words will determine also the plural in all these cases: casalcasas/librol libros/pueblo/ pueblos ext. If the nouns end in a "vowel with tilde" the "es" is added, excluding some exceptions: rubí-rubies/sofá-sofás/café-cafés ext. The "es" is added to nouns ending in consonants as well: proyectores/ universidades. Nouns' ending in " $\mathrm{z}$ " this letter is changed by the "c" and "es" is added: cruzl cruces/ lápizl lápices ext.

\section{Grammar Patterns-Definite and Indefinite Articles}

The acquisition and application of definite/indefinite articles in Spanish FL language classes is another complex issue to comprehend and digest for $2 \mathrm{~L}$ learners whose native-language does not apply these syntaxes in the way Spanish does. Nevertheless, knowing theses linguistic-application-views it will lead to certain analyzes and understanding: in Spanish the definite articles are used to determine and to give a connotation to the nouns they refer to. For example, saying "The white horse". It is not the same as to say "A white horse". In the first case we refer to a specific horse among many. In the second case we refer to any horse among many. The definite articles are also the grammatical components which determine the gender of nouns ending in " $e$ " " ista" El estudiante./La estudiante./EI dentista./La dentista. In the case of "neutrality and cognation" the article " $l o$ " is used, but it followed by a masculine adjective $L o$ Bueno./Lo malo. Lo intersante. On the other hand, the indefinite articles do not give the same connotation to the nouns they refer to as the definite articles do. However, when it comes to "determiners" they do as quantifiers (un/una instead of uno which means one). The definite articles are the English equivalent of "the", while the indefinite articles are the English equivalent of "a, an, some/few" (see Table 2). Despite the differences between these two grammar themes; both, definite and indefinite articles show agreement in gender and number (see Table 3 ).

Table 2. English/Spanish definite and indefinite articles.

\begin{tabular}{cccc}
\hline English Definite Article & \multicolumn{3}{c}{ Spanish Definite Articles } \\
\hline The & el & los & lo \\
& la & las & \\
English Indefinite Articles & & Spanish Indefinite Articles & unos \\
A, an & un & unas \\
\hline
\end{tabular}


Table 3. Definite and indefinite articles gender and number.

\begin{tabular}{ccccc}
\hline Articles & Singular/Masculine & Singular/Feminine & Plural/Masculine & Plural/Feminine \\
\hline Definite & el & la & los & las \\
Indefinite & un & una & unos & unas \\
\hline
\end{tabular}

\section{Grammar Patterns-Adjectives}

When it comes to noun-description for instance, color, size, quality, etc., it is impossible to do without using adjectives. In this regard the function of these grammar themes in the writing and speaking context of Spanish language communication is similar to other languages. However, the application of adjectives and descriptive adjectives in Spanish is subjected to the characteristics (male/female/singular/plural) of the nouns they described. The same-patterns apply when the adjectives are preceded by definite/indefinite articles. So, once again the keyword to better understand the use of adjectives and descriptive adjectives is "acknowledging". Generally, there are basic rules to apply adjectives in Spanish: the adjectives ending in "o" are masculine, to get the feminine therefore it matches the feminine-nature of the noun "o" is replaced by "a" (Hombre alto./Mujer alta.). Adjectives ending in "consonant" are masculine, to get the female therefore it matches the feminine-nature of the noun an " $a$ " is added after the consonant (habador/habladora). This rule applies to living creatures only. Adjectives ending in " $e$ " and "ista" are neuter; they do not have gender. These kinds of adjectives agree with the nouns they describe in singular and plural only:

Auto grande. Casa grande./Autos grandes. Casas grandes.

Hombre optimista. Hombres optimistas./Mujer optimista./Mujeres optimistas.

\section{Adjectives-Outstanding-Note}

When it comes to noun-color/origin-description; it would be very useful to acknowledge that colors are adjectives and to define the origin of people, objects, things, and places we have to use adjectives of nationality. So, there are also basic rules to apply them into the writing and speaking context of Spanish language communication: colors ending in "o" are masculine, to get the feminine therefore it matches the feminine-nature of the noun "o" is replaced by "a". Colors ending in " $\mathrm{e}$ " "a" "consonant" are neuter, they agree with the nouns they describe in singular and plural only. Adjective of nationality ending in "o" and "consonant" are masculine. To get the feminine therefore it matches the feminine-nature of the noun "o" is replaced by "a" and an "a" is added after those ending in consonant. The adjectives of nationality ending in " $\mathrm{e}$ " "i" "a" are neuter, they agree with the nouns they describe in singular and plural only. The adjective of nationality are not written with capital letters in Spanish:

Auto blanco. Casa blanca./Cinto verde. Camisa verde./Zapato azul. Pantufla azul.

Chico japonés. Chica japonesa./Chicos japoneses./Chicas japonesas. 
Barco español./Música española.

\section{Grammar Patterns-Agreement and Words-Order}

In Spanish language there is something that we call "concordancia", this is nothing else than linking many linguistic components into a mutual agreement, I would say. A true example of "concordancia" is the linguistic and lexical agreement between definite/indefinite articles, nouns and adjectives in the speaking and writing context of Spanish language communication (E1 auto rojo./Un auto rojo.). I would personally name such extraordinary arrangement "The three Musketeers of the Spanish language" due to the undoubted value in terms of gender and number usage. Apart from this insight, one thing to ponder is the position the adjectives in phrases/sentences. In Spanish adjectives are written after the nouns, although there are some exceptions in relation to this, it is a general rule. Even though some scholars recommend using the similarity that exists between Spanish and other languages to acquire and enhance the Spanish-lexical (Erichsen, 2015). Spanish second-language-learners have to acknowledge in their minds that each language uses the lexicon according to its own linguistic standards. One example of writing-context to cite is the composition of adjective-phrases in English which translated to Spanish they become noun-phrases:

An easy language./ Una lengua fácil.

The White House./ La Casa Blanca.

$A$ wonderful day./ Un día bonito.

$A$ big university./ Una universidad grande.

An interesting book./ Un libro interesante.

Anold friend./ Un viejo amigo.

Along distance./ Una distancia larga.

The red dress./El vestido rojo.

The blue sky./ El cielo azul.

The black cat./ El gato negro.

A small chair. Una silla pequeña.

An ancient text. Un texto antiguo.

The short girl. La chica baja.

The handsome boy. El chico guapo.

An excellent idea./ Una idea excelente.

A green apple./ Una manzana verde.

\section{Communication-Insights}

According to Rivera (Rivera, 2019) communication is instigated to express human experiences and traits. It is the channel through which an individual can communicate his thoughts. The most common approach used by an individual for communicating is through speaking or writing. These skills require a good understanding of language to be used, particularly its grammar. In this regard having a good 
command of Spanish grammar concerning the use of nouns-object/thing/place; definite/indefinite articles and descriptive adjectives will give an individual the advantage to organize the language in the writing and speaking context of Spanish language communication. To support this insight the study provides various examples of Spanish language communication setting and subsequent-explanations:

Q \& A

Transmitter. ¿Cómo está el café?

Receiver. bueno, malo, caliente, frío.

Transmitter. ¿Cómo está la pasta?

Receiver buena, mala, deliciosa.

Referring to the title.

El señor./ La señora. El doctor./La doctora./ Quiero hablar con ell la señor-a.

Responding to the reference pointed.

¿Qué es esto/ eso/ aquello?

Un libro/ una pizarral un lápiz/ una goma

Describing physical characteristics.

Yo tengo el pelo negro, corto y liso./ Yo tengo los ojos negros./ Yo tengo la piel morena.

Asking and responding the mode.

¿Cómo está el café?/¿Cómo está la leche?/¿Cómo están los pasteles/¿Cómo están las galletas?

Bueno, malo, amargo, dulce ext./Buenas, malas, saladas ext.

Expressingpreferences and wishes.

Me gusta el café./Me gusta la leche./Me gustan los dulces./Me gustan las frutas./Quiero comerpollo frito./Quiero beber jugo de mango./Quiero tomar helado de chocolate./ Quiero tomar sopa de pescado.

Asking and responding the opinion.

¿Qué tal el libro que te presté? ¿Qué tal la película de ayer?

Interesante/ bueno/ interesantel buena

Expressing the existence.

Hay un auto en el garaje./ Hay una casa en esa esquina.

Expressing possessions.

Tengo un auto nuevo./ Tengo una bicicleta nueva. Tengo unos libros muy interesantes. Tengo unas revistas de moda muy interesante. El mío./ La mía./ Los míos./Las mías.

\section{Making comparisons.}

El pescado es mejor que el huevo./La carne es mejor que las verduras./Los dulces son mejores que las frutas./ Las frutas son mejores que las golosinas.

Expressing the superlative.

El mayorlla mayor/los mayores/las mayores/el más joven/la más joven/los más jóvenes/ las más jóvenes.

The examples illustrated show how relevance is the use of nouns, definite and indefinite articles and descriptive adjectives in these cases of communication. In the first example I referred to two ways of communication in which the articles 
and nouns agree in gender and number. So, the adjectives used in the answers respond to the gender and number of the nouns used in the questions. In the second example I referred to the title, in Spanish we use the definite articles in dependence to the male/female/singular/plural to refer to the title that a person holds. In the third example I referred to how to answer the reference pointed, in such case we use indefinite articles before the nouns. In the fourth example I referred to how to ask and answer mode, something that is impossible to do without using nouns, definite articles and descriptive adjectives in such situation. In the fifth example I referred to express preferences, in such situations the definite articles always precede the nouns in the grammar construction of I like.../I don't like... mainly referring to things. In case of expressing wishes; usually the definite articles don't precede the Spanish nouns "I want to eat..."/"I want to drink..." In the sixth example I referred to ask and answer the opinion, such situation requires the use of definite articles and adjectives. In the seventh example I referred to expressing the existence, something that requires the use of the indefinite articles "un/una" if it is wanted to quantify the existence of "a person, an object, a place". In the eighth example I referred to express possession, in this situation is common to use indefinite articles to emphasize in Spanish. In the ninth example I referred to make comparisons, the use of definite articles is required in these situations in Spanish. In the tenth and last example I referred to express the superlative, this grammar subject requires the use of definite articles in Spanish. As could be seen; using nouns-object/thing/place, definite/indefinite articles, and descriptive adjectives in Spanish language is a relevance subject-matter. The main reason regarding "language-difficulties" is due to the use of gender and number and the words-order with which they are treated in Spanish grammar (Gómez Torrego, 2006). This is nothing else than "own linguistic typologies", a Spanish-linguistic-fact that must be conscious to achieve it.

\section{Methodology-Schemes}

At present, the acquisition of Spanish grammar through the use of inductive learning is most recommended by academics as per Linguistics. The inductive approach allows learners to develop through analytical ways and cognitive skills. Learners observe and analyze a feature of the target language first and then they study the rule that explains that feature. On the other hand, the deductive approach focuses on the learning of grammar from the perspective of "grammar rules" first (Prince \& Felder, 2006). In the inductive approach, if the grammatical content only presents a limited number of variables and the function rule is evident, using it may be the most appropriate. However, when the linguistic content that one wants to teach presents many irregularities or the rule is not obvious, then the inductive teaching may be too time consuming, and effort wasting compared to the deductive. Therefore, the most effective strategy may be the combination of inductive and deductive teaching (Castañeda, 1997). In this respect (combination of inductive and deductive teaching) setting appropriate 
methods for teaching and learning the three Spanish grammar themes presented in this research article should be a matter of concern among Spanish Language Teachers. According to the outline of the common European framework for languages (Consejo de Europa, 2001) as well as the American Council on the Teaching of Foreign Languages (2012); the teaching and learning of nouns, definite/indefinite articles and descriptive adjectives corresponds to the levels A1 and A2. This means that these linguistic themes are to be taught from the beginning of the teaching and learning process of Spanish language. Thus, let us remember as Spanish language teachers that the own-linguistic-characteristics of Spanish language will allow the introduction of these Spanish grammar themes from the very beginning too, particularly when it comes to nouns and adjectives. For instance, which Spanish teachers have not been questioned by students when they are taught something as simple as: Buenos días./Buenas tardes./Buenas noches. The usual question from the students: why buenos and buenas and buenas? What is the difference? This seems to be a simple thing, but if we analyze the grammatical and lexical components used in these phrases we would realize that they are "adjectives and nouns" in which the use of gender and number is presented. So, considering this reality, the first thing we should do is to give students the response based on what is said, which does not take long. Then, and not to lose the first chance in helping students to begin acknowledging this necessary Spanish language-topic, giving to them as "a task" studying the didactic material that explains explicitly the use of gender and number in nouns-object/ thing/place, definite/indefinite articles, and descriptive adjectives. It is necessary explain to students about this use as it will be required in the class on the alphabet. The class of the alphabet is often taught after the introduction of greetings and farewells. Well, here we have another chance to deepen further in teaching and learning these syntaxes. Ask students to make up an alphabet of nouns-object/ thing/place, present it in class and then identify the gender of these words, this can be done through a game if desired, for which the new technologies (computer tools applications) can be used, for example, "Kahoot". During the classtopic-discussion set an exercise which consists in writing nous-phrases. For example, if the letter A is said and written the word "auto", with the use of definite/indefinite articles and descriptive-adjectives one can say/write a phrase: " $E I$ auto blanco"./Un auto blanco. These examples of phrases show the concordance between the articles + noun + adjectives and they are addressed to empower the acquisition of the linguistic competence with regard to the use of (gender, number, and word-order) in the writing and speaking context of Spanish language communication.

\section{Example}

Abecedariol Artículos D/I Nombre + Adjetivo

A. auto auto

\section{Communicative Competence Approach}

The Communicative competence is the ability of a person to behave effectively 
and appropriately in a given speech; and this demands from speakers to have a good command of the language (grammar, vocabulary, phonetics, semantics) ext. Hence, it is impossible to ignore the role of "linguistic competence" in "communicative competence" if the speech requires the use of nouns-object/thing/place, definite/indefinite articles and descriptive adjectives. So, with emphasis on both, the linguistic/communicative-competences; we can provide to students a set of exercises based on Q/A that requires the obligatory use of these Spanish grammars themes:

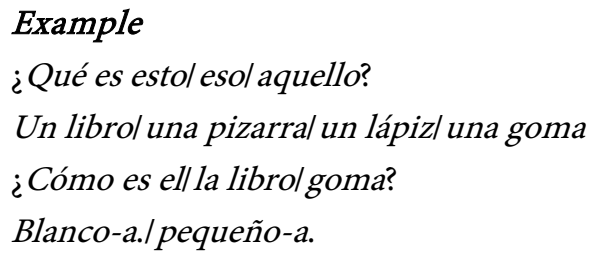

\section{Objective of the Research}

The core intention of this study has been to provide a valuable script as reference for teaching and learning Spanish grammar on the topics of Nouns Object/Thing/Place, Definite and Indefinite Articles and Descriptive Adjectives. In line with the main objective of the manuscript the research article has displaced throughout its headings and sub-headings significant among of collected and added data which can validate the research article-literature and prove its authenticity. In order to corroborate confidentiality in the finding of this research-article; the results; discussion and conclusion as follow.

\section{Results and Discussion}

This study was conducted based on close observations in teaching and learning Nouns Object/Thing/Place; Definite and Indefinite Articles; Descriptive Adjectives in Spanish language classes at Multimedia University (MMU), Malaysia. These observations were based on analyzing the acknowledgement of Spanish language own linguistic characteristics. The reference topics were the role of memory in SLA; the application of grammar; the act of communication. The results showed that Spanish 2L language learners whose native-language does not apply the grammar themes questioned in this research-article the way Spanish does are prone to commit mistakes in correctly applying them in Spanish. The reasons can be traced to factors such as learning-language-retention which cause is based on no acknowledging own language grammar characteristics; Direct and inappropriate translations; Insufficient knowledge about the usage of nouns-object/ thing/place, definite/indefinite articles and descriptive adjectives; The influence of negative external sources in terms of learning choices and the design of specific teaching and learning Spanish grammar lessons to overcome the challenges that the current grammar teaching methodology (grammar must be acquired by students in an inductive way) suggested. Regarding methodology the study discussed the use of inductive and deductive approaches in teaching Spanish 
grammar and the significant of the methodology provided in this research article as appropriate vehicle in teaching and learning the Spanish grammar-themes highlighted. This reference-method has already been used in Spanish language classes conducted at Multimedia University (Malaysia). To validate its efficacy a statistical analysis was carried out among a group of students from level A1 once they had finished the course. This analysis was carried out through a set of questions. The questions were directed to investigate the level of understanding; acquisition; application of the linguistic aspects of Spanish grammar discussing in this manuscript. According to the responds the results showed a significant improvement in the acquisition and develop of cognitive skills and language competences. Thus, this study discussed the significant of acknowledging specific language characteristics in order to acquire and develop the linguistic-competence that involves the use of nouns-object/thing/place, definite/indefinite articles and descriptive adjectives in the speaking and writing context of Spanish language communication. Generally, this is focused "Spanish-grammar-topic", and although the degree of difficulty that Spanish grammar presents has led many to drop out from Spanish school-classes and also stacking many students with regard to the study of the grammar, this discipline continues to be the arbiter that regulates the writing and speaking context of this language, irrespective of pragmatic and socio-cultural factors that also determine its use. Even though it is not an easy task for Spanish 2L language learners retain in their minds the use of gender and number and the words-order with which these Spanish grammar themes presented are treated in the writing and speaking context of Spanish language communication; the literature-content of this research-article-paper will allow these learners and Spanish language teachers managing the subject-matter discussed accordingly.

\section{Conclusion}

On examining the data provided throughout the headings and sub-headings in this research article, one could conclude that the manuscript contains significant literature sources corresponding to the main objective of the research article. The data presented in the manuscript contextualize clearly the subject-matter (Acknowledging Specific Language Characteristics). In this respect, the study has presented a suitable literature material and methods with emphasis on Spanish Language communication setting such as Nouns-Object/Thing/Place; Definite and Indefinite Articles and Descriptive Adjectives. Among many significant finding-results, the study has drawn the attention of a phenomenon (learning-language-retention) and its cause, which is an open door to be studied by the field of Neurolinguistics. By considering the professional view from other researchers about the interest shown among scholars related to the high level of complexities that these Spanish syntaxes present in terms of Second Language Acquisition (SLA), I would respectfully say that this study-research is a response to that concern and an upright-modest contribution letting at the disposition of 
readers and the specialized critics for its evaluation.

\section{Acknowledgements}

The author is very thankful to all the associated personnel in any reference that contributed in/for the purpose of this research.

\section{Funding}

The research is not funded through any source.

\section{Conflicts of Interest}

The research holds no conflict of interest.

\section{References}

(2015). Diccionario de la lengua española (23rd ed.). Madrid: Espasa.

American Council on the Teaching of Foreign Languages (2012). https://www.actfl.org/publications/guidelines-and-manuals/actfl-proficiency-guideline s-2012

Batchelor, R. E., José, S., \& Ángel, M. (2010). A Reference Grammar of Spanish. Cambridge: Cambridge University Press.

Bialystok, E. (1981). The Role of Linguistic Knowledge in Second Language Use. Studies in Second Language Acquisition, 4, 31-45. https://doi.org/10.1017/S0272263100004265

Castañeda, A. (1997). Aspectos cognitivos en el aprendizaje de una lengua extranjera. Granada: Lingüística y Método.

Consejo de Europa (2001). Marco Común Europeo de Referencia para las Lenguas: Aprendizaje, enseñanza, evaluación. http://cvc.cervantes.es/obref/marco

Erichsen, G. (2015). Grammatical Differences between Spanish and English.

Gómez Torrego, L. (2006). Hablar y escribir correctamente: Gramática normativa del español actual.

Prince, M. J., \& Felder, R. M. (2006). Inductive Teaching and Learning Methods: Definitions, Comparisons, and Research Bases. Journal of Engineering Education, 95, 123-138. https://doi.org/10.1002/j.2168-9830.2006.tb00884.x

Rivera, J. (2019). Applied Linguistic-Tú and Usted Spanish Personal Subject Pronouns. Open Journal of Modern Linguistics, 9, 12-24. https://doi.org/10.4236/ojml.2019.91002

Rutherford, W., \& Sharwood Smith, M. (1988). Grammar and Second Language Teaching. A Book of Readings. Rowley, MA: Newbury House. 


\section{Additional Biography}

August, D., Calderón, M., \& Carlo, M. (2002). The Transfer of Skills from Spanish to English: A Study of Young Learners. Washington DC: Center for Applied Linguistics.

Austin, J. L. (1962). Cómo hacer cosas con palabras. Barcelona: Paidós.

Azahares, F., \& Miladys, T. (2011). Características del inglés cuyo conocimiento puedes ser útil al que se dispone a estudiarlo.

Bachman, L. (1990). Habilidad lingüística comunicativa (pp. 105-129).

Berlok, K. D. (2008). El proceso de la comunicación (introducción a la teoría y la práctica). El Ateneo.

Bertuccelli, M. (1993). Qué es la pragmática. Barcelona: Paidós.

Calderón, M., August, D., Durán, D., Madden, N., Slavin, R., \& Gil, M. (2003). Spanish to English Transitional Reading: Teacher's Manual. Baltimore, MD: The Success for All Foundation.

Canale, M., \& Swain, M. (1980). Fundamentos teóricos de los enfoques comunicativos. Signos, 17, 56-61.

De Bruyne, J. (1996). A Comprehensive Spanish Grammar. Hoboken, NJ: Wiley-Blackwell.

Giovannini, A., Martín Peris, E., Rodríguez, M., \& Simón, T. (1996). Profesor en acción 2. Madrid: Edelsa.

Gómez Torrego, L. (2006). Hablar y escribir correctamente: Gramática normativa del español actual.

Hymes, D. H. (1972). Acerca de la competencia comunicativa (pp. 27-47).

Jiménez, M., Antonio, J., Muñoz Marquina, F., Mora, S., \& Ángel, M. (2011). Lenguaje y comunicación. Lengua Castellana y Literatura.

Ortega Olivares, J. (1990). Gramática, pragmática y enseñanza de lenguas. Granada: Actasdel I Congresode ASELE.

Pérez, Á., Sala, R., \& Santamarina, M. (1994). Cassell's Contemporary Spanish. London: MacMillan.

Vermunt, J. D., \& Verloop, N. (1999). Congruence and Friction between Learning and Teaching. Learning and Instruction, 9, 257-280.

https://doi.org/10.1016/S0959-4752(98)00028-0 